\title{
A Novel Graphical Contemporary Perspective ABG Interpretation
}

\author{
Dr. T. Rajini Samuel M.D* \\ Shri SathyaSai Medical College and Research institute, Sri Balaji Vidyapeeth Deemed to be University, \\ Guduvancherry - thiruporur main road, Ammapettai, kancheepuram district, Tamilnadu, India
}

*Corresponding Author: Dr. T. Rajini Samuel M.D, Assistant Professor of Biochemistry, Shri SathyaSai Medical College and Research institute, Sri Balaji Vidyapeeth Deemed to be University, Guduvancherrythiruporur main road, Ammapettai, kancheepuram district, Tamilnadu, India

\begin{abstract}
Arterial Blood Gas analyser is one of the most important point of care testing in the management of critically ill patients. Usually, the measured parameters like $\mathrm{pH}, \mathrm{pCO} 2$ and calculated parameters like HCO3and Standard Base Excess values are utilized for interpretation of various acid base disturbances. A novel contemporary perspective interpretation method for Arterial Blood Gas (ABG) was recently developed by the current author in which the net changes in $\mathrm{pH}$ is related to both the changes in respiratory and nonrespiratory (metabolic) component affecting the $\mathrm{pH}$. The aim of the current study is to represent this perspective $A B G$ interpretation in a four quadrant graphical method for better understanding and correlation. A total of 250 arterial blood gas sample data's were utilized, classified into various groups and the changes in $\mathrm{pH}$ due to respiratory and non-respiratory component is calculated for all the cases. The magnitude and the changes in direction either positive denoting the alkaline effect or negative denoting the acidic effect is clearly observed, graphically analysed and correlated in all the acid base disturbances.
\end{abstract}

Keywords: Arterial Blood Gas, Non-Respiratory Hydrogen Ion Concentration, Novel Perspective Interpretation Method, Four Quadrants Graphical Tool

\section{INTRODUCTION}

Arterial blood gas analyser is one of the most important point of care testing that has immense value in the management of critically ill patients.[I]An increase in the burden of coronary heart disease, diabetes mellitus, chronic obstructive pulmonary diseases (COPD), asthma ,renal failure and trauma patients enhanced the requirement of blood gas analysers due to the rise in the number of patients treated in the emergency department and critical care units but at the same time, the complex and arduous task of interpreting the blood gas analysis report act as a restraining factor for the same.[I-III]

The first postulate of acid base balance theory proposed by the current author (Rajini Samuel) states that the net changes in total $\mathrm{pH}$ is due to both the changes in respiratory and nonrespiratory(metabolic) component affecting the $\mathrm{pH}$. [III, IV]Based on this concept, a novel ABG interpretation method was developed by the current author correlating the net changes in total or actual $\mathrm{pH}[\Delta \mathrm{pH}]$ with the changes in respiratory $[\Delta \mathrm{RpH}]$ and non-respiratory (metabolic) component $[\Delta \mathrm{NRpH}]$ affecting the $\mathrm{pH} .[\mathrm{II}, \mathrm{III}]$ In this current research study, this novel interpretation of Arterial Blood Gas analysis is depicted in a four quadrant graph for better understanding and correlation.

\section{Materials ANd Methods}

The measured $\mathrm{pH}, \mathrm{pCO} 2$, bicarbonate and standard bicarbonate values are noted. The standard base excess or extracellular base excess- cBase (ECF) is calculated using the most commonly used algorithm in ABG analyser.[V,VI]

$\mathrm{cBase}(\mathrm{ECF})=\mathrm{cHCO}_{3}-24.8+16.2 \times(\mathrm{pH}-7.40)$ 


\subsection{Newly Derived Ratios}

These novel ratios are derived using bicarbonate, standard bicarbonate and carbonic acid values.[V-VIII]

Ratio $1=\mathrm{HCO}_{3} / \mathrm{Std} \mathrm{HCO}_{3}$

Ratio $2=\left(\mathrm{HCO}_{3}-\mathrm{Std} \mathrm{HCO}_{3}\right) / \mathrm{H}_{2} \mathrm{CO}_{3}$

Ratio 3 = Ratio $1 \mathrm{X}$ Ratio 2

The carbonic acid concentration $(\mathrm{mmol} / \mathrm{L})$ was calculated by the given formula.

$$
\mathrm{H}_{2} \mathrm{CO}_{3}=0.03 \mathrm{X} \mathrm{pCO}_{2}
$$

\subsection{Non-Respiratory Hydrogen Ion Concentration (Nrh+)}

The calculated hydrogen ion concentration equivalent of standard bicarbonate is called the 'nonrespiratory hydrogen ion concentration' (Hydrogen ion concentration at non-respiratory $\mathrm{pH}^{\mathrm{H}} \mathrm{pCO}_{2}$ $40 \mathrm{~mm}$ of $\mathrm{Hg})$. [IV, IX]

$$
\begin{aligned}
\mathrm{NRH}^{+} & =\{24 \mathrm{X} \mathrm{pCO}\} / \mathrm{Std} \mathrm{HCO}_{3} \\
& =\{24 \mathrm{X} 40\} / \mathrm{Std} \mathrm{HCO}_{3}(\mathrm{pCO} 2 \text { is } 40 \mathrm{~mm} \text { of } \mathrm{Hg}) \\
\mathrm{NRH}^{+} & =960 / \mathrm{Std} \mathrm{HCO}_{3} ; \mathrm{NRpH}=9-\log \left[\mathrm{NRH}^{+}\right]
\end{aligned}
$$

The relation between $\mathrm{NRH}^{+}$and standard bicarbonate shown in the graph 1 clearly depicts that the shape of the graph is rectangular hyperbola and as $\mathrm{NRH}^{+}$increases, the standard bicarbonate decreases and vice versa. The relation between non-respiratory $\mathrm{pH}$ and standard bicarbonate is shown in the graph 2.

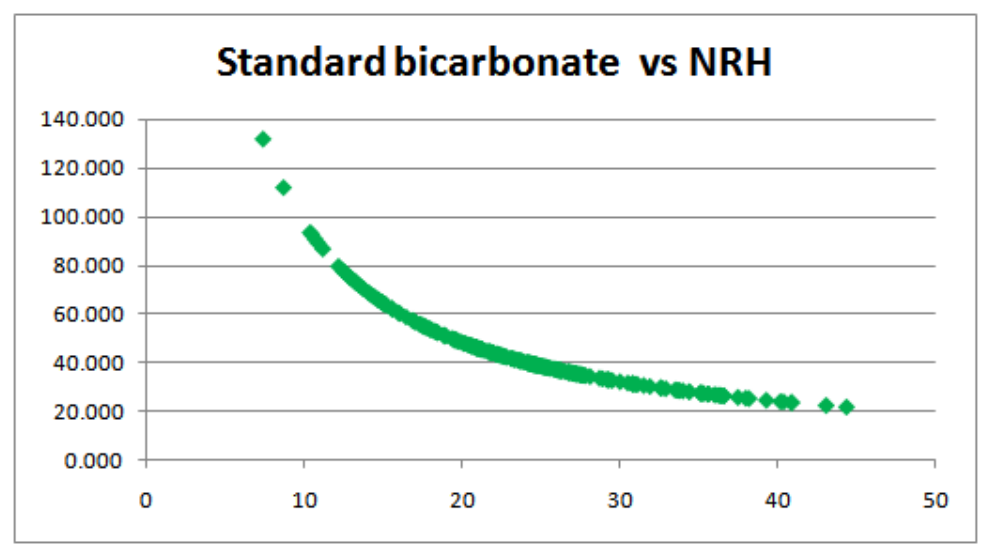

Graph1. $X$ axis: Std Bicarbonate VS Y axis: $N R H^{+}$

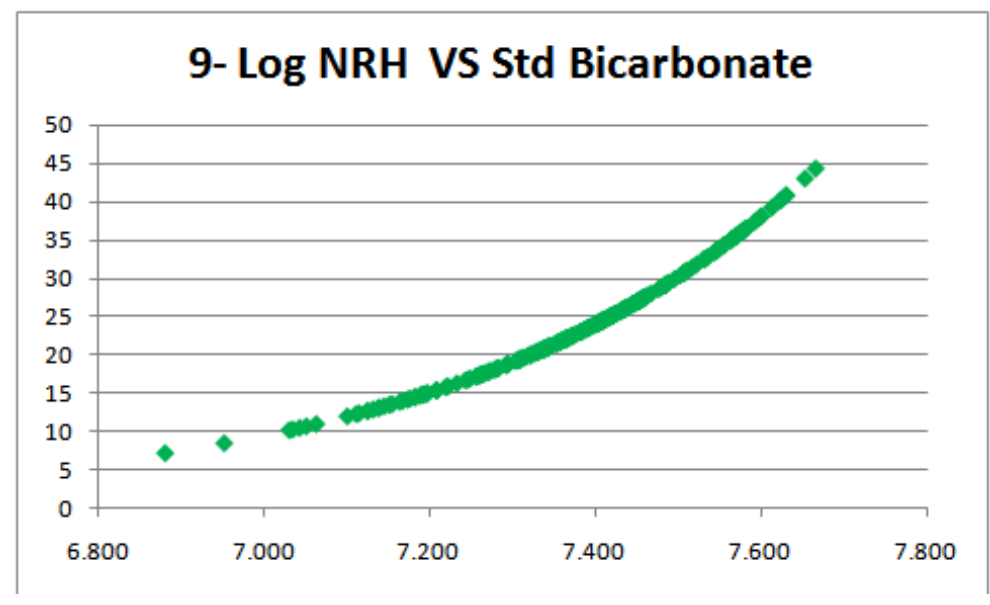

Graph2: X axis: 9- Log NRH VS Y axis: Std Bicarbonate

\subsection{Net Changes in Total PH}

The net changes in Total $\mathrm{pH}($ Actual $\mathrm{pH})$ includes both the changes in respiratory and non-respiratory (metabolic) component affecting the $\mathrm{pH} .[\mathrm{IV}, \mathrm{X}, \mathrm{XI}]$ 
$\Delta \mathrm{pH}=\Delta \mathrm{RpH}+\Delta \mathrm{NRpH}$

$\Delta \mathrm{pH}=[\mathrm{pH}-7.4] \quad$ (net changes in Total or Actual $\mathrm{pH}$ )

$\Delta \mathrm{NRpH}=[\mathrm{NRpH}-7.4] \quad$ (changes due to Non-respiratory component)

$\Delta \mathrm{RpH} \quad=[\mathrm{pH}-7.4]-[\mathrm{NRpH}-7.4]$

$\Delta \mathrm{RpH}=[\mathrm{pH}-\mathrm{NRpH}]$ (changes due to Respiratory component)

\subsection{Calculation of $\Delta \operatorname{rph}(\mathrm{Ph}-\mathrm{Nrph})$}

The derivations are already published in previous research articles by the current author.[III,IV]

$\Delta \mathrm{RpH}(\mathrm{pH}-\mathrm{NRpH})=\log 40+\log \left\{\left(\mathrm{HCO}_{3} / \mathrm{StdHCO}_{3}\right) / \mathrm{pCO}_{2}\right\}$

(the value of $\log 40$ is 1.6 )

$\Delta \mathrm{RpH}(\mathrm{pH}-\mathrm{NRpH})=1.6+\log \left(\mathrm{HCO}_{3} / \mathrm{Std}_{\mathrm{HCO}_{3}}\right)-\log \left(\mathrm{pCO}_{2}\right)$ or

$\Delta \mathrm{RpH}(\mathrm{pH}-\mathrm{NRpH})=1.6+\log \left\{\left(\mathrm{HCO}_{3} / \mathrm{Std} \mathrm{HCO}_{3}\right) / \mathrm{pCO}_{2}\right\}$

\section{ReSUlts}

A total of 250Arterial Blood Gas sample data's were utilized and classified into various acid-base disorder groups based on their normal ranges. The normal reference for arterial blood $\mathrm{pH}$ is 7.35 to 7.45 , for $\mathrm{pCO} 2$ is $35-45 \mathrm{~mm}$ of $\mathrm{Hg}$ and for bicarbonate is $22-26 \mathrm{mEq} / \mathrm{L}$ ormmol/L. The various groups are tabulated in the tables 1 and2. The net changes in total or actual $\mathrm{pH}[\Delta \mathrm{pH}(\mathrm{pH}-7.4)]$ denoting both the changes in respiratory $[\Delta \mathrm{RpH}(\mathrm{pH}-\mathrm{NRpH})]$ and non-respiratory(metabolic) component $[\Delta \mathrm{NRpH}(\mathrm{NRpH}-7.4)]$ affecting the $\mathrm{pH}$ were applied for all the cases for different acidbase disorder groups.

Table1. Normal and Respiratory Acid-base Disorder Groups

\begin{tabular}{|c|c|c|}
\hline Groups & Type of Acid Base Disorder & Number of Cases \\
\hline Group I & Normal: & $\mathbf{2 5}$ cases \\
\hline Group II & Respiratory acidosis & $\mathbf{3 2}$ cases \\
\cline { 2 - 3 } & Respiratory acidosis $1\left(\mathrm{pCO}_{2}>45 \leq 60 \mathrm{~mm}\right.$ of Hg$)$ & 11 cases \\
\cline { 2 - 3 } & Respiratory acidosis $2\left(\mathrm{pCO}_{2}>60 \leq 80 \mathrm{~mm}\right.$ of $\left.\mathrm{Hg}\right)$ & 14 cases \\
\cline { 2 - 3 } & Respiratory acidosis $3\left(\mathrm{pCO}_{2}>80 \mathrm{~mm}\right.$ of $\left.\mathrm{Hg}\right)$ & 7 cases \\
\hline \multirow{3}{*}{ Group } & Respiratory alkalosis & $\mathbf{5 3}$ cases \\
\cline { 2 - 3 } & Respiratory alkalosis $1: \mathrm{pCO}_{2} 31$ to $34 \mathrm{~mm}$ of Hg & 22 cases \\
\cline { 2 - 3 } & Respiratory alkalosis $2: \mathrm{pCO}_{2} 26$ to $30 \mathrm{~mm}$ of $\mathrm{Hg}$ & 8 cases \\
\cline { 2 - 3 } & Respiratory alkalosis 3: $\mathrm{pCO}_{2} 21$ to $25 \mathrm{~mm}$ of Hg & 7 cases \\
\cline { 2 - 3 } & Respiratory alkalosis $4: \mathrm{pCO}_{2} \leq 20 \mathrm{~mm}$ of Hg & \\
\hline
\end{tabular}

Table2. Metabolic Acid-base Disorder and Missellaneous Groups

\begin{tabular}{|c|c|c|}
\hline Groups & Type of Acid Base Disorder & Number of Cases \\
\hline \multirow{5}{*}{$\begin{array}{l}\text { Group } \\
\text { IV }\end{array}$} & Metabolic acidosis & 47 cases \\
\hline & Metabolic acidosis $1\left(\mathrm{HCO}_{3}>18 \leq 22 \mathrm{mmol} / \mathrm{L}\right)$ & 10 cases \\
\hline & Metabolic acidosis $2\left(\mathrm{HCO}_{3}>15 \leq 18 \mathrm{mmol} / \mathrm{L}\right)$ & 12 cases \\
\hline & Metabolic acidosis $3\left(\mathrm{HCO}_{3}>10 \leq 15 \mathrm{mmol} / \mathrm{L}\right)$ & 17 cases \\
\hline & Metabolic acidosis $4\left(\mathrm{HCO}_{3} \leq 10 \mathrm{mmol} / \mathrm{L}\right)$ & 8 cases \\
\hline \multirow{4}{*}{$\begin{array}{l}\text { Group } \\
\text { V }\end{array}$} & Metabolic alkalosis & 34 cases \\
\hline & Metabolic alkalosis $1\left(\mathrm{HCO}_{3}>40 \mathrm{mmol} / \mathrm{L}\right)$ & 12 cases \\
\hline & Metabolic alkalosis $2\left(\mathrm{HCO}_{3}>30 \leq 40 \mathrm{mmol} / \mathrm{L}\right)$ & 12 cases \\
\hline & Metabolic alkalosis $3\left(\mathrm{HCO}_{3}>26 \leq 30 \mathrm{mmol} / \mathrm{L}\right)$ & 10 cases \\
\hline \multirow{4}{*}{$\begin{array}{l}\text { Group } \\
\text { VI }\end{array}$} & Missellaneous further divided into Sub-groups & 59 cases \\
\hline & $\begin{array}{c}\text { Missellaneous1: } \\
\text { Decreased } \mathrm{pH}, \text { increased } \mathrm{pCO}_{2} \text { with decreased } \mathrm{HCO}_{3}\end{array}$ & 11 cases \\
\hline & $\begin{array}{l}\text { Missellaneous 2: } \\
\text { Normal } \mathrm{pH} \text {, increased } \mathrm{pCO}_{2} \text { with Increased } \mathrm{HCO}_{3}\end{array}$ & 20 cases \\
\hline & $\begin{array}{c}\text { Missellaneous 3: } \\
\text { Normal pH, Decreased } \mathrm{pCO}_{2} \& \text { Decreased } \mathrm{HCO}_{3}\end{array}$ & 28 cases \\
\hline
\end{tabular}

From the normal reference level of $\mathrm{pH}$, the normal level of $\Delta \mathrm{pH}(\mathrm{pH}-7.4)$ is calculated as \pm 0.05 . If the $\Delta \mathrm{pH}$ is $<-0.05$, it denotes acidic $\mathrm{pH}$ and if the $\Delta \mathrm{pH}$ is $>+0.05$, it denotes alkaline $\mathrm{pH}$. Then the 
value of $\Delta \mathrm{pH}$ is compared with the values of $\Delta \mathrm{RpH}$ (more negative for respiratory acidosis and more positive for respiratory alkalosis) and $\Delta \mathrm{NRpH}$ (more negative for metabolic acidosis and more positive for metabolic alkalosis). $\Delta \mathrm{NRpH}(\mathrm{NRpH}-7.4)$ is calculated using the relation, $\{\Delta \mathrm{pH}=\Delta \mathrm{RpH}$ $+\Delta \mathrm{NRpH}\}$ where this $\Delta \mathrm{pHis}$ calculated using the measured $\mathrm{pH}$.

\section{DISCUSSION}

The standard bicarbonate values are used to calculate the 'Non-respiratory hydrogen ion concentration'(NRH)which are used to derive an equation denoting the respiratory influence of $\mathrm{pCO} 2$ in causing changes in $\mathrm{pH}$ that plays a key role in the understanding of this novel perspective Arterial Blood Gas interpretation.[III]The magnitude and direction (positive or negative) of the changes in the parameter $\Delta \mathrm{RpH}(\mathrm{pH}-\mathrm{NRpH})$ denotes the respiratory influence in causing changes in $\mathrm{PH}[\mathrm{III}, \mathrm{IV}]$

$\mathrm{PH}-\mathrm{NRpH}=\log 40+\log (\mathrm{HCO} 3 /$ Std HCO3 $)-\log (\mathrm{pCO} 2)$

From the above relation it is very clear that, at $\mathrm{pCO} 240 \mathrm{~mm}$ of $\mathrm{Hg}$, the value of $[\mathrm{pH}-\mathrm{NRpH}]$ is zero. (Standard bicarbonate and bicarbonate values are equal at pCO2 $40 \mathrm{~mm}$ of $\mathrm{Hg}$; $\log 1$ is zero). At higher pCO2 levels (> $40 \mathrm{~mm}$ of $\mathrm{Hg}$ ), the value of $[\mathrm{pH}-\mathrm{NRpH}]$ is negative which denotes the acidic influence of increased pCO2.At lower levels of pCO2 values $(<40 \mathrm{~mm}$ of $\mathrm{Hg})$, the value of $[\mathrm{pH}-$ $\mathrm{NRpH}$ ] is positive which denotes the alkaline influence of decreased pCO2.[III,IV]

It is very clear that $\Delta \mathrm{RpH}$ value is negative for increased pCO2 (>40 mm of $\mathrm{Hg}$ ) and positive for decreased pCO2 ( $<40 \mathrm{~mm}$ of $\mathrm{Hg})$ which are clearly shown in the graph 3 . Their relationship is not strictly proportional, because the respiratory influence of $\mathrm{pCO} 2$ in changing $\mathrm{pH}$ through bicarbonate is a variable one (ratio $\mathrm{HCO} / \mathrm{Std} \mathrm{HCO} 3$ ) depending on the acute or chronic conditions or compensations. [III]

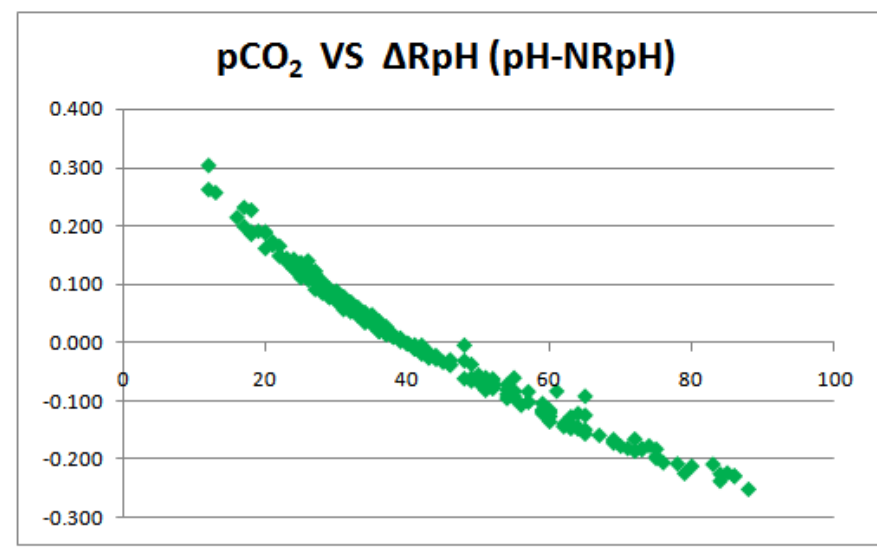

Graph3: $\mathrm{X}$ axis: $\mathrm{pCO}_{2} \mathrm{VS} Y$ axis: $\triangle \mathrm{RpH}(\mathrm{pH}-\mathrm{NRpH})$

The values of ratio 2 or ratio 3 are negative for $\mathrm{pCO} 2$ lesser than $40 \mathrm{mmHg}$ and positive for $\mathrm{pCO} 2$ greater than $40 \mathrm{mmHg}$.[V-VIII]The value of $\Delta \mathrm{RpH}$ is more negative for respiratory acidosis and more positive for respiratory alkalosis(shown in the graphs $3 \& 4$ ) which is opposite to the values of ratio 2 or ratio 3.Similarly, the negative value of $\Delta \mathrm{RpH}$ is more positive for respiratory acidosis and more negative for respiratory alkalos is which is similar to the values of ratio 2 or ratio 3 (shown in the graph 5).

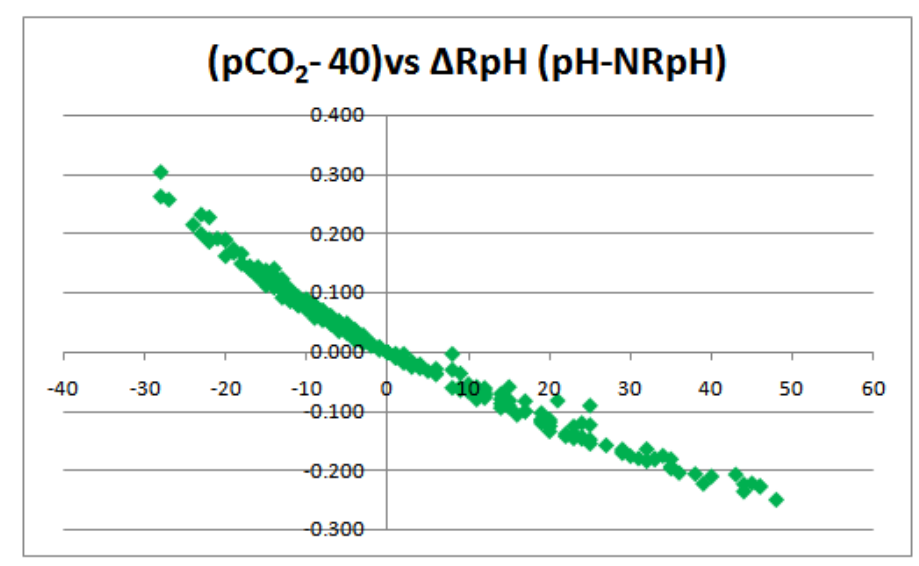

Graph4. $\mathrm{X}$ axis: $\left(\mathrm{pCO}_{2^{-}}\right.$40) VS Y axis: $\triangle \mathrm{RpH}(\mathrm{pH}-\mathrm{NRpH})$ 


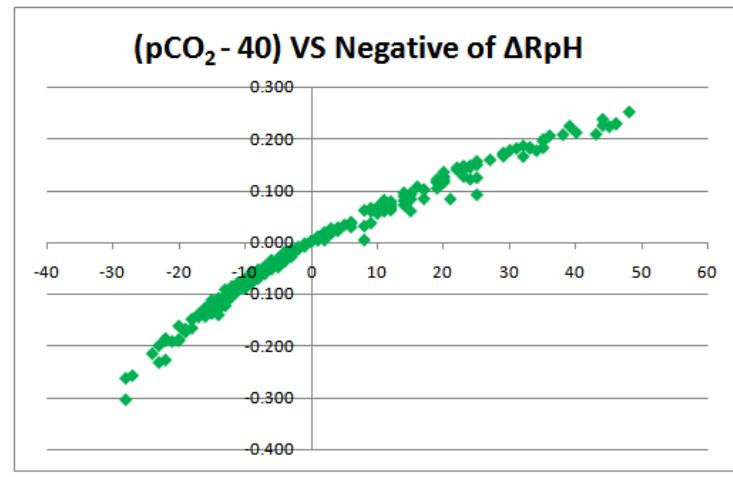

Graph5. $\mathrm{X}$ axis: ( $p \mathrm{CO}_{2^{-}}$40) VS Y axis: Negative of $\triangle \mathrm{RpH}(\mathrm{pH}-\mathrm{NRpH})$

The low non-respiratory hydrogen ion concentration $(\mathrm{NRH}+)$ or a high non-respiratory $\mathrm{pH}$ is seen in metabolic alkalosis which is related to a higher value (more positive) of base excess. Base deficit (lower or more negative value of base excess) is related to a higher non-respiratory hydrogen ion concentration (NRH+) or a low non-respiratory $\mathrm{pH}$ which is seen in metabolic acidosis cases.[IV] The relation between standard Base Excess and the parameter $\Delta \mathrm{NRpH}(\mathrm{NRpH}-7.4)$ is shown in the graph 6.The value of $\Delta$ NRpHis more negative for metabolic acidosis and more positive for metabolic alkalosis which is similar to the standard base excess.

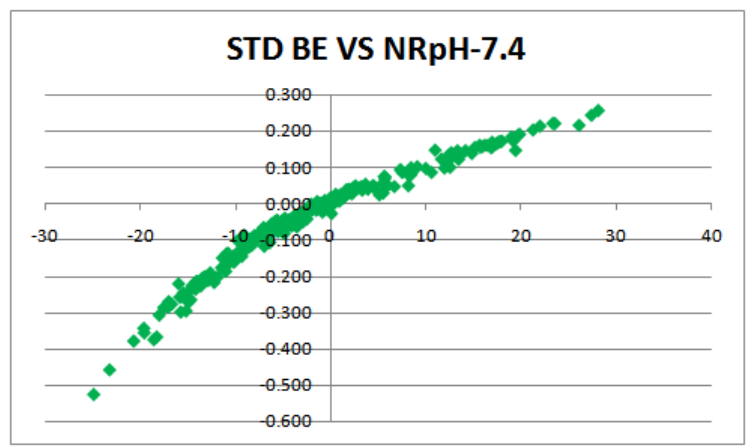

Graph6. $X$ axis: Std Base Excess VS Y axis: NRpH-7.4

A graphical tool constructed using standard base excess (STD BE) in the $\mathrm{x}$ axis and the parameter (pCO2- $40 \mathrm{~mm}$ of $\mathrm{Hg}$ ) in the $\mathrm{y}$ axis clearly demarcates the various acid-base disturbances which is clearly shown in the graph 7.[II,V,XII]Normal Cases are seen around the centre of the graph with various acid-base disorders plotted in the 4 quadrant graph will occupy any of the 4 quadrant which is tabulated in the table 3. Simple acid base disorders are located towards Single Axis( either $\mathrm{x}$ axis or y axis) and Combined acid base disturbances ( compensations or mixed disorders ) are seen in between them (between $\mathrm{x}$ axis and $\mathrm{y}$ axis).

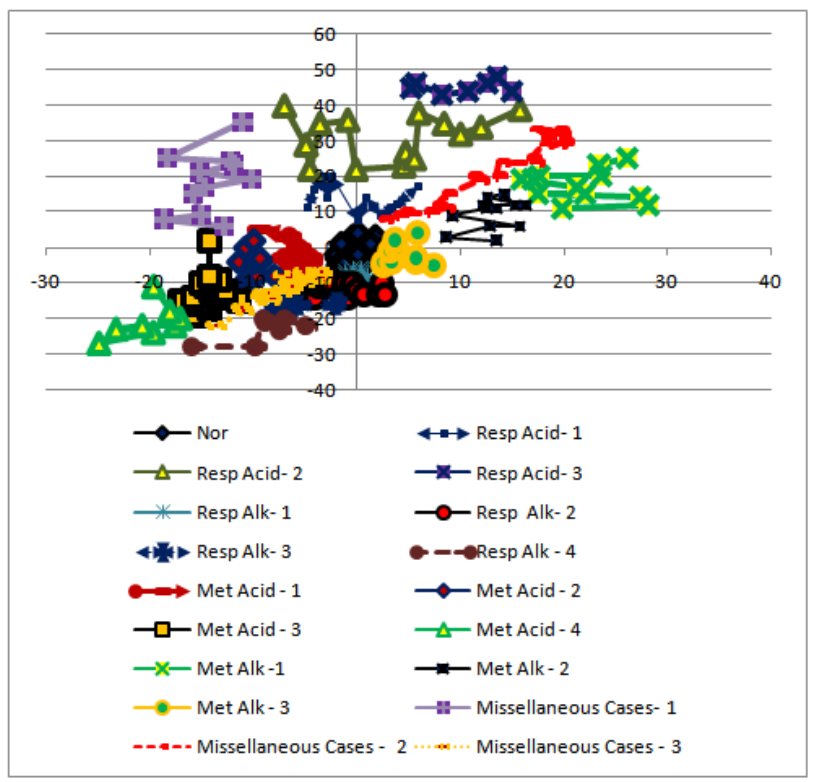

Graph7. Graphical Tool - X axis: STD BE VS Y axis: $\mathrm{pCO}_{2}-40 \mathrm{~mm}$ of $\mathrm{Hg}$ 
Table3. Acid Base Disorders in a Four Quadrant Graphical Tool

\begin{tabular}{|c|c|c|c|c|}
\hline \multirow{2}{*}{$\begin{array}{l}\text { PLOTTED } \\
\text { AREA }\end{array}$} & \multicolumn{4}{|c|}{ Quadrant in the Graphical Tool } \\
\hline & $\begin{array}{l}\mathbf{1}^{\text {st }} \text { quadrant: } \\
\text { both } x \text { axis and } \\
y \text { axis are } \\
\text { positive }\end{array}$ & $\begin{array}{l}\mathbf{2}^{\text {nd }} \text { quadrant : } \mathrm{x} \\
\text { axis positive and } \mathrm{y} \\
\text { axis negative }\end{array}$ & $\begin{array}{l}3^{\text {rd }} \text { quadrant : } \\
\text { both } \mathrm{x} \text { axis and } \\
\mathrm{y} \text { axis are negative }\end{array}$ & $\begin{array}{l}4^{\text {th }} \text { quadrant: } \\
\mathrm{x} \text { axis negative } \\
\text { and y axis } \\
\text { positive }\end{array}$ \\
\hline $\begin{array}{l}\text { Towards } \\
\text { X: Axis } \\
\end{array}$ & $\begin{array}{l}\text { Metabolic } \\
\text { Alkalosis } \\
\end{array}$ & $\begin{array}{c}\text { Metabolic } \\
\text { Alkalosis } \\
\end{array}$ & Metabolic Acidosis & $\begin{array}{l}\text { Metabolic } \\
\text { Acidosis }\end{array}$ \\
\hline $\begin{array}{l}\text { Towards } \\
\text { Y: Axis }\end{array}$ & $\begin{array}{l}\text { Respiratory } \\
\text { Acidosis }\end{array}$ & $\begin{array}{l}\text { Respiratory } \\
\text { Alkalosis }\end{array}$ & $\begin{array}{l}\text { Respiratory } \\
\text { Alkalosis }\end{array}$ & $\begin{array}{l}\text { Respiratory } \\
\text { Acidosis }\end{array}$ \\
\hline $\begin{array}{l}\text { In } \\
\text { Between } \\
\text { Them }\end{array}$ & $\begin{array}{l}\text { Metabolic } \\
\text { Alkalosis and } \\
\text { Respiratory } \\
\text { Acidosis }\end{array}$ & $\begin{array}{l}\text { Metabolic } \\
\text { Alkalosis and } \\
\text { Respiratory } \\
\text { Alkalosis }\end{array}$ & $\begin{array}{l}\text { Metabolic Acidosis } \\
\text { and } \\
\text { Respiratory } \\
\text { Alkalosis }\end{array}$ & $\begin{array}{l}\text { Metabolic } \\
\text { Acidosis and } \\
\text { Respiratory } \\
\text { Acidosis }\end{array}$ \\
\hline
\end{tabular}

5. NOVEL ABG INTERPRETATION METHOD

A four quadrant graphical tool can be constructed similar to the previously published graphical tool (constructed using standard base excess and ratio 2 or ratio 3 ) using different parameters $(\Delta$ NRpHin the $\mathrm{x}$ : axis and the negative of $[\Delta \mathrm{RpH}]$ in the y: axis) which is shown in the graph 8 . A novel ABG interpretation method was developed by RajiniSamuel correlating the net changes in total or actual $\mathrm{pH}$ $[\Delta \mathrm{pH}]$ with the changes in respiratory $[\Delta \mathrm{RpH}]$ and non-respiratory (metabolic) component $[\Delta$ $\mathrm{NRpH}]$ affecting the $\mathrm{pH} .[\mathrm{III}]$

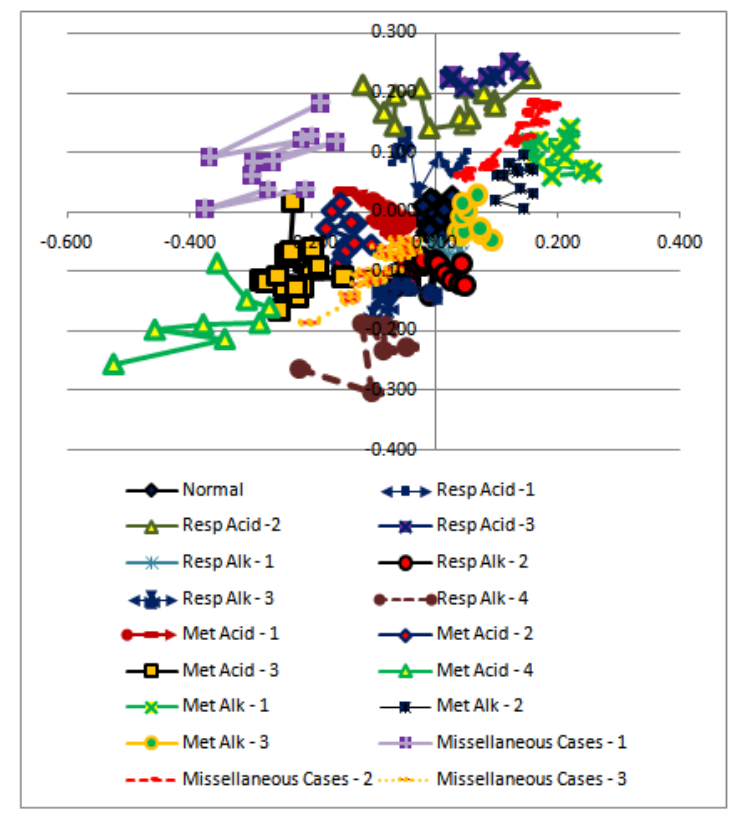

Graph8. Graphical Tool - X axis: $\triangle$ NRpH VS Y axis: Negative of $\triangle R p H$

The value of $\Delta \mathrm{NRpH}$ is more negative for metabolic acidosis and more positive for metabolic alkalosis which is similar to the standard base excess. Similarly, the negative value of $\Delta \mathrm{RpH}$ is more positive for respiratory acidosis (increased $\mathrm{pCO} 2$ ) and more negative for respiratory alkalosis (decreased pCO2) which is similar to the ratio 2 or ratio 3 values. If changes in both the components $(\triangle \mathrm{NRpH} \& \Delta \mathrm{RpH})$ are involved, it may denote combined acid base disturbances (either compensatory mechanisms or mixed acid base disorders). If the changes in $\mathrm{pH}$ due to metabolic and respiratory component are equal but opposite, then the net change is zero because it is cancelled out each other.[II,III]

The graphical representation will serve as an aiding tool for better ABG interpretation.[XIII,IVX]The application of this novel ABG interpretation in a four quadrant graphical method in this study concludes that it is much easier to observe the changes in magnitude and direction in various acid base disturbances which will help in better understanding of cases presenting with different $\mathrm{pH}, \mathrm{pCO} 2$ and $\mathrm{HCO} 3$ values. 


\section{CONCLUSION}

Arterial blood gas interpretation has immense clinical value in critically ill patients. This novel contemporary perspective method of Arterial Blood Gas (ABG) interpretation depicted in a four quadrant graphical method appears to be much simpler, easier and may serve as a supporting tool for teaching purposes.

\section{REFERENCES}

[1] Dheeraj Kapoor, Meghana Srivastava, and Pritam Singh, Point of care blood gases with electrolytes and lactates in adult emergencies Int J CritIllnInj Sci. 2014 Jul-Sep; 4(3): 216-222.

[2] Rajini Samuel A Graphical Representation For Aiding Arterial Blood Gas Interpretation Using NonRespiratory And Respiratory pH WJPMR, 2018,4(12), 192-202

[3] T. Rajini Samuel, BalajiRajagopalan, Uma Maheshwari. A novel contemporary perspective teaching method for interpretation of various acid base disorders citing with examples. International Journal of Contemporary Medical Research 2019;6(3):C10-C14.

[4] Rajini Samuel T Application and Inter-Relationship of Non-Respiratory Hydrogen Ion Concentration in Acid-Base Balance Theory International Journal of Clinical Chemistry and Laboratory Medicine (IJCCLM), 2018; 4(3): 1-13.

[5] Rajini Samuel T Revised Graphical Tool for ABG Interpretation using Modified Bicarbonate/Standard Bicarbonate Ratio International Journal of Clinical Chemistry and Laboratory Medicine (IJCCLM),2019; 5(3): 19-29

[6] Samuel R. A Graphical Tool for Arterial Blood Gas Interpretation using Standard Bicarbonate and Base Excess. Indian J Med Biochem, 2018; 22(1): 85-89

[7] Rajini Samuel T Application of Modified Bicarbonate/Standard Bicarbonate Ratio In Arterial Blood Gas Interpretation International Journal Of Scientific Research-2019; 8(3): 60-63

[8] Rajini Samuel T Application of standard bicarbonate/carbonic acid ratio in arterial blood gas analysis International Journal of Clinical Biochemistry and Research, 2018;5(2):314 - 320

[9] J. T. SueroThe Usefulness Of Non-Respiratory Hydrogen Ion Concentration And Its Relationship To The Traditional Acid-Base Parameters Clin. Biochem, 1969; 2: 177-185

[10] Whitehead TP. Acid-base status, pH, and PCO2. Lancet 1965; 2:1015-6

[11] Michael J. BookallilDescription of $\mathrm{pH}$ or Acid-Base Status in Blood, $\mathrm{pH}$ of the Blood: AcidBase Balance available online:www.anaesthesia.med.usyd.edu.au/resources/lectures/acidbase_mjb/acidbase.html

[12] T. Rajini Samuel Chapter Who Is Balancing: Is It RBC or Acid-Base Status? Intech Open Publisher ; pages 1-15 DOI: http://dx.doi.org/10.5772/intechopen. 84768

[13] Barnette, L. \&Kautz, D.D. Creative ways to teach arterial blood gas interpretation. Dimensions of Critical Care Nursing (DCCN), 2013; 32(2): 84-87.

[14] Doig AK, Albert RW, Syroid ND, Moon S, Agutter JA. Graphical arterial blood gas visualization tool supports rapid and accurate data interpretation Comput Inform Nurs, 2011; 29(4): 53-60

Citation: Dr. T. Rajini Samuel M.D, "A Novel Graphical Contemporary Perspective ABG Interpretation". International Journal of Clinical Chemistry and Laboratory Medicine (IJCCLM), 5(4), pp.11-17, DOI: http://dx.doi.org/ 10.20431/2455-7153.0504003.

Copyright: $\odot 2019$ Authors. This is an open-access article distributed under the terms of the Creative Commons Attribution License, which permits unrestricted use, distribution, and reproduction in any medium, provided the original author and source are credited. 